\title{
EFFECT OF FERMENTED AND UNFERMENTED MUCUNA BEAN SEED, ON GROWTH PERFORMANCE OF TILAPIA
}

\author{
G. N. WOKE, L. P. ALELEYE-WOKOMA, G. W. KOMI AND D. O. BEKIBELE
}

(Received 2 June 2010; Revision Accepted 31 October 2012)

\begin{abstract}
The effect of fermented and unfermented Mucuna (Mucuna pruriens utilis) seed on growth performance of the Nile Tilapia, Oreochromis niloticus (L.) Trewavas, was investigated in eight weeks feeding trial in concrete tanks. Three approximately isonitrogenous diets were fed to three sets of fingerlings of Oreochromis niloticus. Specific growth rate (SGR), average weight gain, (AWG), percentage weight gain (FWG), food conversion ratio (FCR) and protein efficiency ratio (PER) were not significantly different $(P>0.05)$ from the control. However, crude protein, ash and nitrogen free extract of the carcass composition were significantly different $(P>0.05)$. Fish weight ranged from L75+0.14 - 5.60+089, 2.13 $\pm 0.43-5.67+1.46$ and $1.45 \pm 0.12-4.87 \pm 0.64$ for DI, D2 and D3 respectively. The average weight gains were $3.85 \mathrm{~g}, 3.54 \mathrm{~g}$ and $3.42 \mathrm{~g}$ for DI, D2 and D3 respectively. Average apparent food consumed is in the order D2 >D1 > D3. Fermented Mucuna seed diet (D2) has the highest food conversion ratio of 1.51 followed by the control diet 1.22 and 1.19 for D3. Diet 3 is the most cost effective of the three diets. D3 has the highest food efficiency (0.84) followed by DI (0.82) and the least D2 (0.66). Results of this study appear to show that unfermented Mucuna diet can conveniently replace Soya bean based diet for feeding Oreochromis niloticus.
\end{abstract}

KEYWORDS: Mucuna bean, substitution, efficiency and cost effectiveness

\section{INTRODUCTION}

Mucuna pruriens utilis, an underutilized tropical legume, has a nutritional quality comparable to Soya bean and other Conventional Legumes as it contain similar proportion of protein, Lipids, minerals and other nutrients. Recently the processed velvet bean are exploited as a protein source in the diet of fish, poultry, pig and cattle. Although the velvet bean contain high level of protein and carbohydrate, their utilization is limited due to a number of anti-nutritional/antiphysiological compounds, phenolics, tannins, L-Dopa, lectins, protease, inhibitors, etc. which may reduce the nutrients utilization (Pugalenthi et ah, 2005).

Mucuna grain has great potentials in animal feed. According to Kay (1979) and Buckles (1995), an important use of Mucuna grain in the USA in the early part of this Century was as animal feed.

In aquaculture, diets generally represent the largest single cost item of most fish farm operation. It, therefore, follows that the selection of feed ingredients for use within diets will play a major role in dictating the ultimate nutritional and economic success of farmed fish.

Soya bean is widely used to supplement fishmeal because of its rich protein content. The essential amino acid composition of alternative protein sources are not comparable with that of fishmeal considering that the apparent chemical score data show that there is no single foodstuff that can serve as an alternative to fishmeal (Desilva and Anderson, 1995).

Amongst the identified local feed ingredients in Nigeria, wheat bran, cattle blood and Soya bean meal are ideal industrial by-product for feed processing. They represent carbohydrate, animal protein and plant protein sources necessary for fish feed formulation(Bekibele, 2007). The same is also true for livestock species such as pigs and broilers. While livestock such as poultry and pigs are able to utilize carbohydrates as the major source of energy, fish species are able only to digest fair amounts of carbohydrates in their diets, the digestible carbohydrates sparing the protein for tissue building (Bekibele, 2007).

Since the Nile Tilapia is a typical example of herbivorous and detritivorous fish, they generally require higher levels of dietary protein for optimum growth (Tacon and Cowey 1985). like other fishes and land animals, Tilapia requires all the ten essential amino acids namely; Arginine, histidine, isoleucine, lysine, valine, phenylalanine, methionine, tryptophan, leusine and threonine. Of these, lysine and methionine are often the first limiting amino acids. Fish feeds prepared with plants (Soybean-meal) protein typically are low in methionine; therefore, extra methionine must be added to Soybean-meal based diets in order to promote optimal growth and health. It is important to know and

G. N. Woke, Department Animal and Environmental Biology, Fisheries and Hydrobiology Unit, University of Port Harcourt Nigeria

L. P. Aleleye-Wokoma, Department Animal and Environmental Biology, Fisheries and Hydrobiology Unit, University of Port Harcourt Nigeria

G. W. Komi, Department Animal and Environmental Biology, Fisheries and Hydrobiology Unit, University of Port Harcourt Nigeria

D. O. Bekibele, African Regional Aquaculture Centre Aluu, Port Harcourt. Nigeria. 
match the protein requirements and the amino acid requirements of each fish species reared.

Protein levels in aquaculture feeds generally average 32-38\% for tilapia (Landau, 1992; Steven and Helfrich, 2002). Protein requirements usually are lower for herbivorous fish and omnivorous fish than they are for carnivorous fish and are higher for fish reared in high density (recirculation aquaculture) than low density (pond aquaculture) systems (Steven and Helfrich,2002). Protein requirements are generally higher for smaller fish. As fish grow larger, their protein requirement usually decrease(Harris, 1980). Protein requirements also vary with rearing environment, water temperature and water quality as well as the genetic composition and feeding rates offish. Protein is used for fish growth if adequate levels of fats and carbohydrates are present in the diet. If not, protein may be used for energy and life support rather than growth.

\section{MATERIALS AND METHODS}

\section{COMPOSITION AND PREPARATION OF DIETS}

Full Fat Soya - Full fat Soya (prepared from soya bean) used for the experiment was obtained from African
Regional Agriculture Centre/Nigerian Institute of Oceanography and Marine Research (ARAC/NIOMR) Aluu, Port Harcourt.

Unfermented Mucuna Seed - Dry mature seed of Mucuna pruriens var. utilis was obtained from International Institute of Tropical Agriculture (IITA), Ibadan. The seed was soaked overnight, ground, dried and preserved in an air-tight plastic container for later use.

Fermented Mucuna Seed - Dry mature seed of Mucuna pruriens var utilis which was obtained from IITA Ibadan was soaked overnight, boiled for 45 minutes, ground and fermented for 48 hours using yeast. Thereafter dried in an oven at $60 \mathrm{C}$.

Other Ingredients - The other ingredients - wheat bran, fishmeal, garri, palm oil, premix, bone meal and vitamin $\mathrm{C}$ - used in the formulation were obtained from the ARAC/NIOMR feed mill. The proximate composition of full fat soya, unfermented Mucuna seed and fermented Mucuna seed used for the experimental diets are presented in Table 1

Table 1: Proximate composition of full fat Soya, fermented and unfermented Mucuna seed.

\begin{tabular}{|l|l|l|c|c|c|c|}
\hline Item & Moisture & $\begin{array}{l}\text { Crude } \\
\text { protein }\end{array}$ & NFE/CHO & Lipids & Ash & $\begin{array}{l}\text { Crude } \\
\text { fibre }\end{array}$ \\
\hline Full fat soya & 7.40 & 35.00 & 16.43 & $\mathbf{1 7 . 6 0}$ & 4.90 & 18.40 \\
\hline $\begin{array}{l}\text { Fermented } \\
\text { Mucuna }\end{array}$ & 7.60 & 24.94 & 35.10 & 4.20 & 2.90 & 25.27 \\
\hline $\begin{array}{l}\text { Unfermented } \\
\text { Mucuna }\end{array}$ & 9.30 & 24.50 & 38.99 & $\mathbf{4 . 4 0}$ & 2.10 & 20.71 \\
\hline
\end{tabular}

\section{DIET FORMULATION}

Diet 1,2 and 3 being full fat soya, fermented mucuna seed and unfermented mucuna seed diets respectively were formulated with 1 as control. About
$45 \%$ of crude protein of soya bean was replaced with mucuna bean protein in both fermented and unfermented mucuna bean diets. The diets were approximately isonitrogenous with the control. Table 2 shows the composition of the experimental feeds.

Table 2: Percentage (\% W/W) Composition of Experimental Diet

\begin{tabular}{|l|l|l|l|}
\hline Ingredients & Control 1 & $\begin{array}{l}\text { Fermented Mucuna } \\
\text { D 2 }\end{array}$ & $\begin{array}{l}\text { Unfermented } \\
\text { Mucuna D 3 }\end{array}$ \\
\hline Wheat bran & 11.30 & - & - \\
\hline Full fat Soya & 50.23 & 20.68 & 20.41 \\
\hline Fermented Mucuna bean & - & 41.95 & - \\
\hline Unfermented Mucuna bean & - & - & 43.08 \\
\hline Fish meal & 25.11 & 24.96 & 24.94 \\
\hline Garri & 5.14 & 4.14 & 3.40 \\
\hline Palm oil & 5.14 & 5.17 & 5.10 \\
\hline Premix & 0.91 & 0.89 & 0.91 \\
\hline Bone meal & 2.05 & 2.07 & 2.04 \\
\hline Vitamin C & 0.11 & 0.15 & 0.11 \\
\hline Total & $\mathbf{1 0 0} \mathbf{k g}$ & $\mathbf{1 0 0} \mathbf{~ k g}$ & $\mathbf{1 0 0} \mathrm{kg}$ \\
\hline
\end{tabular}




\section{MIXING AND PELLETING OF FEED}

Feed ingredients were weighed separately, later mixed together and ground to fine consistency with a pepper grinder. A diesel operated pelleter was used to pellet the meals. The three diets were sun dried separately. Samples of the test diets were analyzed for protein, lipids, moisture, carbohydrate, crude fibre and ash by the standard procedures described by AOAC (1984) as shown in Table 3.

Table 3: Proximate Composition of Diets (\%)

\begin{tabular}{|l|l|l|l|}
\hline Nutrients & Control 1 & \multicolumn{1}{|c|}{ D2 D3 } & \multicolumn{1}{|c|}{ D2 } \\
\hline Moisture & 6.90 & 4.60 & 7.20 \\
\hline Crude protein & 31.94 & 40.69 & 35.88 \\
\hline NFE (CHO) & 22.73 & 22.73 & 25.00 \\
\hline Lipids & 17.60 & 10.80 & 12.10 \\
\hline Ash & 7.80 & 6.50 & 6.40 \\
\hline Crude fibre & 13.03 & 14.68 & 19.82 \\
\hline Total & $\mathbf{1 0 0} \mathbf{~ k g}$ & $\mathbf{1 0 0} \mathbf{~ k g}$ & $\mathbf{1 0 0} \mathbf{~ k g}$ \\
\hline
\end{tabular}

\section{PREPARATION OF EXPERIMENTAL TANKS}

The feeding trials were executed in 9 concrete tanks each measuring $80 \times 60 \times 60 \mathrm{~cm}^{3}$. Before stocking, the tanks were washed thoroughly and supplied with clean water from borehole known to be free of chlorine and planktons.

\section{STOCKING}

Each tank was stocked with 20 fingerlings of hatchery bred Oreochromis niloticus (Nile Tilapia) with average body weight of $2.0 \mathrm{~g}$ and average length of $4.6 \mathrm{~cm}$ purchased from ARAC.

Fingerlings were starved for 24 hours before stocking and three tanks were assigned to each dietary treatment i.e. three replicates of three dietary treatments making up to 9 tanks in a completely randomized design.

\section{FEEDING OF FISH}

The fish were fed their respective diets once daily, for a period of eight (8) weeks at a rate of $3 \%$ total body weight per day. They were fed between 11:00 12:00 hours when dissolved oxygen was high and food consumption at maximum.

Records of feed consumption, weight and length changes were progressively taken at two weeks (fortnightly) intervals. No feeding was done on Sundays and sampling days for convenience.

\section{MEASUREMENT OF THE FISH}

Measurement of the fish weight and length were taken every fortnight to assess the growth rate. Each tank was drained completely, length and total wet weight of fish measured and weighed. After weighing, feeding rates were adjusted in accordance with changes in total wet body weight of fish.

Based on the length and weight changes over the feeding trial period, specific growth rate (SGR), Food Conversion Ratio (FCR), Food Efficiency, Protein efficiency ratio (PER), daily growth rate (DGR) and percentage weight gain (PWG), were determined.

\section{WATER QUALITY}

Water quality in each treatment was monitored once every week. Water $\mathrm{pH}$ and temperature were measured using a pen-type $\mathrm{pH}$ metre with temperature display and dissolved oxygen with Hanna instruments HI8915 ATC.

\section{BIOCHEMICAL ANALYSIS TECHNIQUE}

Soya bean, Mucuna bean and experimental fish were analyzed for crude protein by the modified Kjeldahl Distillation Procedure suggested by William (1964). Colour developed with an improved Nessler's reagent was monitored with colorimeter at a wave length maximum of $520 \mathrm{~nm}$. Ammonium sulphate was used to plot the standard curve, from which milligram nitrogen corresponding to an absorbance reading, was directly obtained. Crude protein was obtained by multiplying total nitrogen by 6.25 . Lipid was obtained by the soxhlet ether extraction method, carbohydrate by Cleg Anthrone method, moisiture by loss on ignition method, Ash by furnace method at $630^{\circ} \mathrm{C}$ according to AOAC (1984) and fibre by difference.

\section{STATISTICAL ANALYSIS}

Performance and body composition parameters were subjected to analysis of variance (ANOVA) and where differences occurred, the means were subjected to Duncan multiple range test,

\section{RESULTS}

PHYSICO-CHEMICAL PARAMETERS OF TANK WATER

The physico-chemical parameters of the tank water with respect to dissolved oxygen as shown in table 4 is relatively low throughout the feeding trial. A mean value of $4.75,4.54$ and 4.76 for DI, D2 and D3 respectively.

Temperature difference was 27.42, 27.54 and 27.36 for DI (control diet), D2 (fermented Mucuna seed diet) and D3 (unfermented Mucuna) respectively. pH reading being $7.09,7.10$ and 7.03 for $\mathrm{DI}, \mathrm{D} 2$ and $\mathrm{D} 3$ 
respectively.

Table 4: Physico-chemical parameters of tank water

\begin{tabular}{|l|l|l|l|}
\hline Parameters & DI (control) & D2 & D3 \\
\hline Dissolved oxygen (D.O) & $4.75 \pm 0.89$ & $4.54 \pm 0.82$ & $4.76 \pm 0.31$ \\
\hline Temperature $\left({ }^{\circ} \mathrm{C}\right)$ & $27.42 \pm 0.30$ & $27.54 \pm 0.56$ & $27.36 \pm 0.11$ \\
\hline $\mathrm{PH}$ & $7.09 \pm 0.16$ & $7.10 \pm 0.08$ & $7.03 \pm 0.11$ \\
\hline
\end{tabular}

Growth response of nile tilapia Oreochromis nileticus

The growth of Nile Tilapia Oreochromis niloticus is progressive with mean weight per fish ranging from 1.75 to 5.60 in $\mathrm{DI}, 2.13$ to 5.67 in D2 and $1.45-4.87$ for D3. Mean length per fingerling of Oreochromis niloticus for DI ranges from 4.63 to 6.87 , D2 ranges from 5.00 to
7.13 and D3 from 4.30 to 6.57 for a trial period of 8 weeks. Average weight gain did not show any statistical significant different $(P>0.05)$ among the control diet $\mathrm{DI}$, fermented mucuna seed diet D2 and unfermented mucuna seed diet D3. Percentage weight gain was also subjected to analysis of variance but did not show any significant difference $(P>0.05)$ among treatments. This is shown in Tables 5,6 and 7

Table 5: Mean weight response of Oreochromis niloticus

\begin{tabular}{|c|c|c|l|}
\hline Week & DI (control) & D2 & D3 \\
\hline Stocking & $1.75 \pm 0.14$ & $2.13 \pm 0.43$ & $1.45 \pm 0.12$ \\
\hline Week 2 & $3.04 \pm 0.56$ & $3.46 \pm 1.13$ & $2.58 \pm 0.50$ \\
\hline Week 4 & $3.98 \pm 0.53$ & $4.51 \pm 1.14$ & $3.20 \pm 0.18$ \\
\hline Week 6 & $4.67 \pm 0.55$ & $5.25 \pm 1.33$ & $4.10 \pm 0.30$ \\
\hline Week 8 & $5.60 \pm 0.89$ & $5.67 \pm 1.46$ & $4.87 \pm 0.64$ \\
\hline
\end{tabular}

Table 6: Mean length growth response of O.niloticus fed experimental diets.

\begin{tabular}{|c|l|l|l|}
\hline Week & DI (control) & D2 & D3 \\
\hline Stocking & $4.63 \pm 0.15$ & $5.00 \pm .46$ & $4.30 \pm 0.10$ \\
\hline Week 2 & $5.13 \pm 0.15$ & $5.57 \pm 0.49$ & $4.93 \pm 0.21$ \\
\hline Week 4 & $5.90 \pm 0.20$ & $6.27 \pm 0.59$ & $5.53 \pm 0.12$ \\
\hline Week 6 & $6.60 \pm 0.40$ & $6.73 \pm 0.50$ & $6.13 \pm 0.06$ \\
\hline Week 8 & $6.87 \pm 0.42$ & $7.13 \pm 0.50$ & $6.57 \pm 0.15$ \\
\hline
\end{tabular}

\section{SPECIFIC GROWTH RATE, VERAGE WEIGHT GAIN AND PERCENTAGE WEIGHT GAIN.}

The values of specific growth rate, average weight gain and percentage weight gain are shown on Table 7. Diet
3 (unfermented Mucuna seed meal) has the highest specific growth rate of 2.13 followed by diet 1 control) with values 2.04 and D2 (fermented Mucuna seed meal) has the least 1.72. However, there is statistically no significant difference among the three diets $\mathrm{P}>0.05$. 
Table 7: Growth Responses and feed utilization parameters of Oreochromis niloticus reared in experimental tanks

\begin{tabular}{|l|l|l|l|l|}
\hline \multicolumn{1}{|c|}{ Parameters } & DI (control) & D2 & D3 & SIG \\
\hline GROWTH RESPONSE & & & & \\
\hline Av. Initial Body weight (g) & $1.75 \pm 0.14$ & $2.13 \pm 0.43$ & $1.45 \pm 0.12$ & \\
\hline Av. Initial Body length (cm) & $4.63 \pm 0.15$ & $5.0 \pm 0.46$ & $4.3 \pm 0.10$ & \\
\hline Av. Final Body weight (g) & $5.60 \pm 0.89$ & $5.67 \pm 1.46$ & $4.87 \pm 0.64$ & \\
\hline Av. Final body length (cm) & $6.87 \pm 0.42$ & $7.13 \pm 0.50$ & $6.57 \pm 0.15$ & \\
\hline Specific Growth Rate (SGR) & 2.04 & 1.72 & 2.13 & N.S \\
\hline Av. Weight gain & 3.85 & 3.54 & 3.42 & N.S \\
\hline Daily weight gain (g/day) & 0.098 & 0.099 & 0.085 & \\
\hline Percentage weight gain & 220.00 & 166.20 & 235.86 & N.S \\
\hline FEED UTILIZATION & & & & \\
\hline Av. Apparent feed consumed (g) & $4.71 \pm 0.83$ & $5.36 \pm 1.76$ & $4.06 \pm 0.40$ & \\
\hline Food Conversion Ratio (FCR) & 1.22 & 1.51 & 1.19 & N.S \\
\hline Food efficiency (FE) & 0.82 & 0.66 & 0.84 & \\
\hline Protein Efficiency Ratio (PER) & 2.57 & 1.62 & 2.34 & N.S \\
\hline Survival (\%) & 97 & 93 & 98 & \\
\hline
\end{tabular}

N.S $={ }^{*}$ No significant difference $(P>0.05)$ among diets DI, D2 and D3. SIG=Significance

The control Diet, 1 produced the highest average weight gain (3.85) in the experimental fish followed by diet 2 (3.54) and D3 (3.42) being the least. When subjected to analysis of variance, there is no significant difference $(P>0.05)$ among DI, D2 and D3.

In terms of percentage weight gain, although there is no significant difference among the three diets ( $P>0.05)$, D3 shows the highest value (235.86) followed by DI $(220,00)$ and D2 (166.20).

Daily weight gain shows that fish fed with diet 2 gained more weight $(0.099)$ on a daily basis than fish fed DI (0.098) and D3 (0.085).
FOOD CONVERSION RATIO, FOOD EFFICIENCY AND PROTEIN EFFICIENCY RATIO (TABLE 7).

Fish fed fermented mucuna seed diet D2 has food conversion ratio of 1.51 which is the highest in the array 1.19, 1.22 and 1.51 for D3, DI and D2 respectively. Food conversion ratio is, however, not statistically significant $(P>0.05)$ among fish fed DI, D2 and D3.

Food efficiency is highest in diet D3 with value (0.84) and lowest in diet 2 with value 0.66 . Soya bean based diet $\mathrm{DI}$ which serves as control has 2.57 as protein efficiency ratio, D2 (1.63) and D3 (2.34). Protein efficiency ratio does not show significant difference among the three diets $(P>0.05)$.

Table 8: Nutrient composition of $O$. niloticus carcass as at the end of feeding trial (\% weight)

\begin{tabular}{|l|l|l|l|l|}
\hline \multicolumn{1}{|c|}{ Parameters } & $\mathrm{B} / \mathrm{F}$ & DI (Control) & D2 & D3 \\
\hline Crude protein & 31.94 & $51.04^{\mathrm{ab}} \pm 2.53$ & $45.79^{\mathrm{b}} \pm 7.85$ & $54.69^{\mathrm{a}} \pm 3.09$ \\
\hline Ash & 22.80 & $11.50^{\mathrm{b}} \pm 1.40$ & $15.30^{\mathrm{a}} \pm 0.76$ & $11.83^{\mathrm{b}} \pm 1.72$ \\
\hline Crude fibre & 17.82 & $5.62 \pm 1.32$ & $7.25 \pm 1.99$ & $6.09 \pm 3.39$ \\
\hline Moisture & 10.70 & $6.33 \pm 0.30$ & $8.86 \pm 2.00$ & $6.83 \pm 1.58$ \\
\hline Lipids & 14.70 & $23.93 \pm 3.35$ & $20.53 \pm 3.11$ & $18.47 \pm 2.80$ \\
\hline Carbohydrate (NFE) & 2.05 & $1.58^{\mathrm{b}} 0.35$ & $2.19^{\mathrm{ab}} \pm 0.38$ & $3.59^{\mathrm{a}} \pm 1.54$ \\
\hline
\end{tabular}

Values in the same row showing common superscript are not significantly $(\mathrm{P}>0.05)$ different. B/F - Before feeding. 
G. N. WOKE. L. P. ALELEYE-WOKOMA. G. W. KOMI AND D. O. BEKIBELE

Table 9: Cost of feed ingredient $[\mathrm{A})$

\begin{tabular}{|l|l|c|c|l|}
\hline \multicolumn{1}{|c|}{ Ingredient } & Cost/kg N & DI (Control) & D2 & D3 \\
\hline Wheat bran & 36.00 & 406.80 & - & \\
\hline Full fat Soya & 140.00 & 7032.20 & 2895.20 & 2857.40 \\
\hline Fermented Mucuna seed & 100.00 & - & 4195.00 & - \\
\hline $\begin{array}{l}\text { Unfermented } \\
\text { Mucuna seed }\end{array}$ & 100.00 & - & & \\
\hline Fish meal & & & & \\
\hline Garri & 350.00 & 8788.50 & 8736.00 & 8729.00 \\
\hline Palm oil & 160.00 & 822.40 & 662.40 & 544.00 \\
\hline Premix & 300.00 & 1542 & 1551.00 & 1530.00 \\
\hline Bone meal & 800.00 & 728 & 712.00 & 728.00 \\
\hline Vitamin C & 40.00 & 82.19 & 82.80 & 81.60 \\
\hline Total cost (N) & 5000 & 570.78 & 750.00 & 550.00 \\
\hline $\begin{array}{l}\text { Apparent feed consumption } \\
\text { (g) }\end{array}$ & - & $19,972.87$ & $19,584.40$ & $19,328.00$ \\
\hline $\begin{array}{l}\text { Cost } \\
\text { consumed (g) }\end{array}$ & - & $4.71+0.83$ & $5.36 \pm 1.76$ & $4.06+0.40$ \\
\hline Av. Weight gain & - & 0.94 & & \\
\hline Cost effectiveness & & & 0.30 & \\
\hline
\end{tabular}

\section{DISCUSSION}

Oreochromis niloticus accepts Soya bean base diet, fermented Mucuna seed diet and unfermented Mucuna seed diet appreciably over the eight weeks feeding trial. Growth parameters such as specific growth rate (SGR) average weight gain, daily weight gain and percentage weight gain did not show significant difference $(P>0.05)$ among the treatment diets.

Both D2 and D3 can conveniently replace Soya bean protein at $45 \%$. In terms of growth and nutrient utilization there is no significant difference $(P>0.05)$. Mucuna bean based diets is as good as Soya bean based diet. This agrees with the findings of Bekibele (2005) that Mucuna beans could replace soya bean meal up to $50 \%$ level in diets for Clarias gariepinus.

In carcass quality, DI and D3 have better quality in terms of protein level. In terms of fish quality, fish fed unfermented Mucuna diet (D3) is better than fish fed Soya bean meal because D3 leads to lower level of carcass lipids.

In storage, the more lipids in fish the poorer the quality of the fish. Fermentation of D2 did not completely remove toxic substance in Mucuna bean, hence method of processing feed is very important. Perumal and Klaus
(2001) in their preliminary nutritional evaluation of Mucuna seed meal (Mucuna pruriens var. utilis) in common carp (Cyprinus carpio L.): an assessment by growth performance and feed utilization reported that no significant differences were observed regarding the whole body moisture, protein, ash and lipid contents among fishes.

However, carcass composition of Oreochromis niloticus showed significant difference $(P>0.05)$ in crude protein, ash and nitrogen free extract, but was statistically not different in crude fibre, moisture and lipids in fish carcasses fed DI, D2 and D3.

Values obtained for dissolved oxygen, $4.75 \pm 089,4.54 \pm 0.82$ and $4.76 \pm 0.31$ for DI, D2 and D3 respectively were below acceptable dissolved oxygen level for fish culture. This is likely responsible for poor growth rates as oxygen availability affect food consumption rate which translate into growth performance of fish. Landau (1992) recommends dissolved oxygen levels of 5 - $9 \mathrm{mg} / \mathrm{l}$ for fingerlings.

Temperature and $\mathrm{pH}$ fell within the acceptable limits of the characteristics of water that could support optimal growth of fish (Landau, 1992).

The analysis of cost effectiveness in Table 9 shows unfermented Mucuna seed meal D3 to be most cost effective. D3 shows that it would require N230.00 to 
produce $1 \mathrm{~kg}$ of wet fish weight against N240.00 that would be needed for DI and N300 for diet 2 (D2).

The cost of unit weight of feed used are $\mathrm{N} 940.00 / \mathrm{kg}, \mathrm{N} 1050.00 / \mathrm{kg}$ and N780.00/kg for DI, D2 and $\mathrm{D} 3$ respectively.

\section{REFERENCES}

Association of Official Analytical Chemists., AOAC, 1984. Official Method of Analysis of the AOAC, AOAC Washington DC; 152-162.

Bekibele, D. O., 2007. The influence of cattle Blood, Wheat bran and palm oil diet on performance and body composition in Avian and fish species Ph.D Thesis Department of Animal Science Rivers State University of Science and Technology, Port Harcourt, 67.

Buckles, D., 1995. Velvet bean: A "new" plant with a history. Economic Botany 49, I3 - 23.

Desilva S.S and Anderson, T. A., 1995. Fish Nutrition in Aquaculture. Chapman and Hall, London 319.

Harris, L. E., 1980. Feedstuff. Fish Feed TechnologyLecture presented at the FAO/UNDP Training course in fish feed Technology held at the College of Fisheries, University of Washington, Seatle, Washington U.S.A. $9^{\text {th }}$ October -15 December 1978. ADCP/REP/80/11. 156157.

Kay, D., 1979. Crop and Product Digest No. 3 - Food Legumes. Tropical Product Institute, London. 435 .

Landau, M., 1992. Introduction to Aquaculture, John Wiley and sons publ. co. USA. 272.

Perumal, S and Klaus, B., 2001. Preliminary nutritional evaluation of Mucuna seed meal (Mucuna pruriens van utilis) in common carp (Cyprinus carpio L.): an assessment by growth performance and feed utilization Elsevier Science, www.sciencedirect.com.

Robinson, E. H and Li, M. H., 1999. Evaluation of practical diets with various levels of dietary protein and animal protein for pond raised channel catfish Ictalurus punctatus J. World Aquaculture Soc. 29. 273-280.

Steven, C and Helfrich, L. A., 2002. Understanding Fish Nutrition, feeds and feeding. Virginia Cooperation Extension Service Publication 420256. ext.vt.edu/pubs/fisheries/420-256/420-256.html.

Tacon, A. G. J and C. B. Cowey., 1985. Protein and Amino Acid Requirement. Ppl35-183. In P. Tyfler and P.Calow (eds). Fish Energy New Perspective. Heln London.
William, P. C., 1964. A Colorimetric Method of Determining Total Crude Protein. Analyst 89.Pp 276-280. 